\title{
Job Research for Medical Skincare by DACUM
}

Sumin Lee ${ }^{1}$, Jaeeun Lee ${ }^{2}$, Haejung Chon ${ }^{1 *}$

${ }^{1}$ Department of International Beauty Design, Seoseoul Life Science High School, guro-gu, Seoul, Korea

${ }^{2}$ Department of Beauty Design, Sungkyul University, Anyang-si, Gyenggi-do, Korea

*Corresponding author: Haejung Chon, Department of Beauty Design, Sungkyul University, 53, Seonggyeoldaehak-ro, Manan-gu, Anyang-si, Gyeonggi-do 14097, Korea

Tel.: +82 314678383

Email: hjchons@hanmail.net

Received May 14, 2021

Revised May 21, 2021

Accepted June 01, 2021

Published June 30, 2021

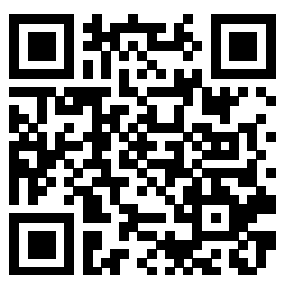

\begin{abstract}
Purpose: This study aimed to systematize the scope of work through a stepwise definition and description of the job of esthetician in medical skincare by applying the developing a curriculum (DACUM) technique. In addition, the importance, difficulty, and frequency of use of the job was checked and provided as basic data that can be used in the medical skincare industry and educational sites. Methods: For the job research of medical skincare workers, a total of five experts with extensive field experience were selected as DACUM members. As a result of DACUM analysis, the jobs of medical skincare workers were derived from 9 duties and 18 tasks. Results: In this study, the job of medical skincare workers was defined as the use of medical devices with a cosmetic medical program and management of cosmeceutical products, which are applied to customers who have been professionally diagnosed with skin problems by a dermatologist. As a result of DACUM, among the medical skincare jobs, the importance, difficulty, and frequency of use of "knowing hospital reception practice," "understanding human anatomy physiological knowledge," and "understanding beauty equipment practice" were high. The importance and frequency of use of "medical hygiene management" were also high. Conclusion: The findings of this study present standardization of medical skincare workers' jobs and provide data for the development of the curriculum.
\end{abstract}

Keywords: Developing a curriculum, Medical skincare worker, Medical skincare, Duty, Task

\section{Introduction}

자기관리의 하나로 외모 행동들이 증가되면서 뷰티 시장의 규모 는 계속적으로 확대되고 있다. 뷰티 산업은 보건, 의료, 문화, 예술, 과학 등과 연계되어 새로운 수요를 창출하고 있으며(Kim, 2015), 이 중에서도 뷰티와 의료는 통합적이고 과학적인 융합시장의 활성화 로 이어지고 있다(Sim, 2015). 메디컬 스킨케어는 초기에는 환자들 의 피부질환이나 잘못된 시술로 인한 문제를 최소화하기 위한 개념 으로 도입되었으나, 의약분업 이후 뷰티 산업이 주목을 받으면서 피 부 재생과 회복을 위한 각종 시술 및 후 처치로 확장되고 있다(Jang, 2017). 의료분야에서 메디컬 스킨케어의 시작은 1 차 의료 기관인 병•의원에서 주로 의료 서비스를 제공하기 위한 목적으로 도입되 었으며, 지속적으로 증가하고 있다(Shin \& Kim, 2009; Mo \& Oh, 2019). 뿐만 아니라 레이저 산업의 발달과 보톡스, 필러 등 다양한 미용 치료법 개발과 함께 메디컬 스킨케어 시장이 질적으로 급격히 성장을 하고 있다(Mo \& Oh, 2019). 또한 최근 코로나 바이러스 감
염증으로 경제 트렌드는 방향보다는 변화의 속도에 집중될 것을 예 측하고 있으며(Kim et al., 2020), 뷰티 시장에서도 소비자들의 뷰티 취향과 트렌드가 빠르게 변화하고 있다. 이전과 같이 피부관리를 위 해 오랜 시간을 투자하던 때와는 달리, 보다 빠른 피부의 개선과 치 료가 가능한 메디컬 스킨케어의 요구도가 높아지고 있다.

이러한 메디컬 스킨케어의 등장과 고객의 다양한 요구에 대응하기 위한 방법 중 새로운 직업 군으로 병원 코디네이터, 병원 서비스 교 육전문가, 병원 미용상담사와 같은 메디컬 스킨케어 전문 인력이 등 장하여 고객의 만족도를 높이며 병원 경쟁력을 강화하고 있다(Kang \& Lee, 2012; Mo \& Oh, 2019). 병원코디네이터는 진료가 원활히 진행될 수 있도록 돕는 것뿐만 아니라 고객이 의료 서비스에 만족할 수 있도록 고객 상담 및 관리와 의료진과 고객 사이에서 의사소통의 매개 역할을 수행하고 있다. 이로 인해 의료 서비스의 질적인 평가 를 높여 그 수요가 점점 증가하고 있다(Kim et al, , 2020). 병원 코디 네이터는 메디컬 스킨케어 분야에서 상위 직급으로 병원의 전반적인 
업무를 계획, 실행하는 등 성과 향상에 직접적인 역량을 발휘할 수 있어야 한다(Yoo et al., 2016). 따라서 메디컬 스킨케어 분야에서 의 료와 미용을 접목한 융합형 인재의 필요성이 요구되어 대학 및 산업 체에서 관련 전문가 양성을 하고 있으며, 병원 내 피부관리실, 비만 클리닉, 두피 클리닉 등으로 취업이 다양화되고 있다(Kim, 2019a).

다양한 직무자들이 수평적인 구조로 이루어져 업무를 분담하는 병 원 시스템에서 메디컬 스킨케어 종사자의 업무 내용을 수준에 따른 직무로 구분하고 단계별로 표준화하는 작업이 필요하다. 의사의 진 료 및 처치와 환자의 건강을 회복하고 유지, 증진할 수 있도록 케어 하는 간호업무에 피부 미용 서비스가 융합되어 각각의 직무의 책무 특성에 맞게 작업을 할 수 있도록 배치되어야 한다. 메디컬 스킨케어 종사자의 직무를 분야별로 살펴보면, 상담과 진료 안내를 담당하는
병원 코디네이터, 환자의 진료와 치료를 원활하게 진행될 수 있도록 돕는 간호사와 간호조무사, 고객의 피부 미용을 담당하는 피부관리 사로 크게 구분할 수 있다. Mo \& Oh (2019)의 연구에 의하면 메디 컬 스킨케어 종사자의 직무의 세분화를 통해 구체적인 수행도와 난 이도에 대한 분석이 필요하다고 하였다. 따라서 본 연구에서는 메디 컬 스킨케어 종사자의 직무 분석을 통해 체계적이고 전문적인 교육 방법을 모색하여 메디컬 스킨케어 종사자의 직무를 단계별로 명확하 게 구분하여 직무의 수행 능력을 높이고자 한다.

현재 메디컬 스킨케어 현장이 지속적으로 성장하고 있고, 종사 자의 필요성이 크게 요구되는 상황임에도 불구하고 Lee \& Choi (2018)의 메디컬 스킨케어 능력 단위 개발을 위한 국가직무능력표준 (National Competency Standards, NCS)을 위한 교육과정을 연구

Table 1. Comparison of medical skincare contents (refer to university materials)

\begin{tabular}{|c|c|c|c|c|}
\hline Unit name & Detailed unit & Textbook A & Textbook B & Textbook C \\
\hline \multirow{3}{*}{$\begin{array}{l}\text { Medical skincare } \cdot \text { Skincare } \\
\text { customer consultation }\end{array}$} & 1. Medical skincare definition and purpose & Y & Y & Y \\
\hline & 2. Skin function, action, and structure & Y & $\mathrm{N}$ & $\mathrm{N}$ \\
\hline & 3. Customer consultation & Y & Y & Y \\
\hline \multirow{5}{*}{ Skin analysis } & 1. Sensitive skin & Y & Y & Y \\
\hline & 2. Atopic skin & Y & Y & Y \\
\hline & 3. Acne skin & Y & Y & Y \\
\hline & 4. Pigmented skin & Y & Y & $\mathrm{Y}$ \\
\hline & 5. Aging skin & Y & $\mathrm{Y}$ & Y \\
\hline \multirow{4}{*}{ Laser } & 1. Laser features & $\mathrm{Y}$ & $\mathrm{Y}$ & Y \\
\hline & $\begin{array}{l}\text { 2. Classification of laser types according to } \\
\text { skin characteristics }\end{array}$ & $\mathrm{Y}$ & Y & Y \\
\hline & 3. How to deal with laser side effects & $\mathrm{N}$ & Y & $\mathrm{N}$ \\
\hline & 4. Post-laser precautions & N & Y & $\mathrm{N}$ \\
\hline \multirow{3}{*}{ Chemical peeling $\cdot$ Skin scaling } & 1. Types and methods of chemical peeling & Y & Y & N \\
\hline & 2. Skin scaling(peeling) types and methods & Y & Y & $\mathrm{N}$ \\
\hline & 3. Side effects and precautions & Y & Y & $\mathrm{N}$ \\
\hline \multirow{2}{*}{ Cosmeceutical. drug type } & 1. Cosmeceutical product features and types & Y & Y & Y \\
\hline & 2. Drug product features and types & Y & Y & Y \\
\hline \multirow{3}{*}{ Scalp care } & 1. Hair physiology & Y & $\mathrm{N}$ & Y \\
\hline & 2. Classification by hair loss type & $\mathrm{N}$ & $\mathrm{N}$ & Y \\
\hline & 3. Treatment of hair loss & $\mathrm{N}$ & $\mathrm{N}$ & Y \\
\hline \multirow{6}{*}{ Obesity management } & 1. Obesity definition & Y & $\mathrm{N}$ & Y \\
\hline & 2. Causes of obesity & Y & $\mathrm{N}$ & Y \\
\hline & 3. Types and classification of obesity & Y & $\mathrm{N}$ & Y \\
\hline & 4. Cellulite & Y & $\mathrm{N}$ & Y \\
\hline & 5. Treatment method & Y & $\mathrm{N}$ & Y \\
\hline & 6. Types of obesity management devices & Y & $\mathrm{N}$ & Y \\
\hline \multirow{2}{*}{$\begin{array}{l}\text { Plastic surgery · Beauty } \\
\text { treatment }\end{array}$} & 1. Types of cosmetic procedures & Y & $\mathrm{N}$ & Y \\
\hline & 2. Types and features of plastic surgery & Y & $\mathrm{N}$ & Y \\
\hline \multirow{2}{*}{ Lymph drainage } & 1. Circulatory system & Y & $\mathrm{N}$ & $\mathrm{N}$ \\
\hline & 2. Lymphatic system & Y & $\mathrm{N}$ & $\mathrm{Y}$ \\
\hline
\end{tabular}

$\mathrm{Y}(\mathrm{Yes})$, content included; $\mathrm{N}$ (No), content not included. 
한 것 이외에 메디컬 스킨케어의 업무분석과 교육과정 개발에 대한 연구는 미비하다. 그러므로 메디컬 스킨케어 시장의 확대로 직무 역 량을 갖춘 인재를 양성하기 위해서는 다양한 연구가 필요하다.

이에 본 연구에서는 메디컬 스킨케어 종사자의 직무를 데이컴 (Developing A Curriculum, DACUM) 기법에 의해 도출하였다. DACUM 기법이란 직무분석을 위한 방법으로 1970년대 미국 오하 이오 주립대학에서 직업교육을 위한 직무분석에 사용하면서 여러 분 야에서 사용되고 있다(Norton, 1997). 이 기법은 해당 직무의 전문 적인 실무자들을 위원회로 구성하고 워크솝을 통해, 직무수행을 위 한 책무(duty), 작업(task)을 도출하여 현장 실무자들의 직무 요구 도를 조사함으로써 교육과정 개발에 반영하는 방법을 말한다. 데이 컴 직무분석 기법은 비교적 짧은 시간 동안 적은 비용으로 서로 상호 작용하면서 실무자들이 제시하는 정보를 분석함으로써 이론과 실제 의 차이를 줄일 수 있는 장점이 있다(Lee et al., 2017). 국내에서도 데이컴 기법을 이용한 응급의료센터 간호사의 직무분석(Yun et al., 2020), 분만실 간호사의 업무 분석(Kim et al., 2015), 에이즈 상담 간호사 자격제도 개발을 위한 직무분석(Kwon et al., 2009), 특성화 고 산학협력부장 교사의 직무 분석(Kim \& Kim, 2018) 등이 있으나, 메디컬 스킨케어 직무에 대한 분석은 전무하다.

따라서 본 연구에서는 DACUM 기법을 이용하여 메디컬 스킨케어 에서 피부관리사의 현행 업무를 분석하고 단계별 업무의 범위를 체 계화하여 메디컬 스킨케어 산업 및 교육현장에서 기초 자료로 제공 하고자 한다.

\section{Methods}

\section{1. 연구목적 및 내용}

본 연구는 DACUM기법에 의한 직무분석 방법을 적용하여 메디 컬 스킨케어 종사자에 대해 정의하고 직무를 도출하여 직무를 기술 하였다. 책무와 작업을 분류하고 중요도, 난이도 및 활용 빈도를 분 석하는 서술적 조사연구로서 본 연구목적을 달성하기 위한 세부 연 구 내용은 아래와 같다.

첫째, 메디컬 스킨케어 종사자 직무의 정의는 무엇인가?

둘째, 메디컬 스킨케어 종사자의 책무와 작업의 요소에는 무엇이 있는가?

셋째, 메디컬 스킨케어 종사자의 직무의 중요도와 난이도, 활용 빈도는 어떠한가?

\section{2. 연구 방법}

첫째, 메디컬 스킨케어 직무를 파악하기 위해 메디컬 스킨케어 직 무의 학습을 위해 집필된 대학교재 중 Pyo et al. (2018), Lee et al. (2013) 및 Kim et al. (2017)의 내용을 참고하였다. 메디컬 스킨케어 직무 내용 정리는 다음 Table 1 과 같다.

둘째, Lee \& Choi (2018)의 메디컬 스킨케어 능력 단위 개발을 위 한 교육과정 연구에서 능력 단위를 추출하고, Lee \& Choi (2015)의 메디컬 스킨케어의 실태 및 만족도에 관한 연구를 참조하여 메디컬 스킨케어의 영역과 유형을 구분하였다. 또 Lee \& Lee (2012)의 피 부과에 근무하는 메디컬 스킨케어 피부관리사의 근무 현황 연구를 참조하여 실무에 필요한 전문지식에 대해 추출하였으며, Mo \& Oh (2019)의 메디컬 종사자의 직무 수행도와 난이도 분석에서 직무와 수행도를 참조하고 확인하였다. 메디컬 스킨케어 직무관련 논문은 다음 Table 2 와 같다.

셋째, Min \& Kim (2019)과 Kwon et al. (2009)의 DACUM 기법 을 활용한 직무 연구 분석을 참조하여 DACUM 위원회 워크숍의 기 초자료를 마련했다. 메디컬 스킨케어 종사자의 직무내용을 도출하기

Table 2. Reference papers on medical skincare job

\begin{tabular}{|c|c|c|}
\hline Form & Medical skincare job & Reference \\
\hline $\begin{array}{l}\text { Medical skincare ability unit } \\
\text { development }\end{array}$ & $\begin{array}{l}\text { Patient service management, Patient response management, Medical service } \\
\text { management, Patient counseling management, Internal customer management, } \\
\text { Skincare customer consultation, Skin Analysis, Skin beauty customer finishing care, } \\
\text { Facial exfoliation management, Use of basic cosmetics for skin beauty products, Risk } \\
\text { Management, Health and medical regulations, Understanding medical services, Medical } \\
\text { terms, Medical communication }\end{array}$ & Lee \& Choi, 2018 \\
\hline Status and satisfaction & $\begin{array}{l}\text { Medical skincare area } \\
\text { Medical skincare types } \\
\text { Medical cosmetics features and status }\end{array}$ & Lee \& Choi, 2015 \\
\hline Work status & $\begin{array}{l}\text { Practical expertise } \\
\text { Customer counseling }\end{array}$ & Lee \& Lee, 2012 \\
\hline Job performance & $\begin{array}{l}\text { Duty: Medical beauty, Cooperation, Utilization of beauty devices, Skincare practice } \\
\text { Fulfillment: Precautions after laser care, Importance of post-medical skincare Botox, and } \\
\text { filler therapy explained } \\
\text { Perform collaboration: medical staff, Coordinator } \\
\text { Performing the utilization of beauty devices: Massage machine, Facial cleansing device } \\
\text { Performing skincare: Laser post-management, Skin nutrition supply, Use of sponge and } \\
\text { wet towel }\end{array}$ & Mo \& Oh, 2019 \\
\hline
\end{tabular}


위해 메디컬 스킨케어 현장 실무경력 10 년 이상의 전문가 2 명, 스킨 케어 전공 대학교수 2 명, 현장 업무 종사자이며 진행자 및 기록자 1 명, 총 5 명으로 DACUM 위원회를 구성하여 3 차례 워크숍을 진행하 였다.

위와 같은 연구 방법을 통하여 구체적인 연구를 실시하였다.

첫째, 메디컬 스킨케어 종사자의 직무 정의를 통해 직무를 도출하 고 기술하였다.

둘째, DACUM 위원회 위원에게 메디컬 스킨케어 종사자 직무의 중요도, 난이도, 활용 빈도 조사를 실시하였다.

셋째, DACUM 기법을 통한 메디컬 스킨케어 직무기술 내용을 수 정 및 보완 과정을 통해 최종 완성하였다.

\section{Results}

\section{1. 메디컬 스킨케어 종사자 직무의 정의}

메디컬 스킨케어 종사자는 피부과 전문의를 통해 피부의 문제에 관해 전문적인 진단을 받은 고객을 미용의료 프로그램을 적용한 의 료기기 사용과 코스메슈티컬 화장품을 이용한 관리를 수행하는 직무 로 정의하였다.

\section{2. 메디컬 스킨케어 종사자의 직무기술}

메디컬 스킨케어 종사자의 직무 모형은 본 DACUM 위원회의 토 의에서 도출된 메디컬 스킨케어 종사자의 직무를 9 개의 책무와 18 개 의 작업으로 이루어졌다. 책무(duty) 영역은 '메디컬 스킨케어 및 병 원 리셉션 실무', '문제성 피부 분석', '레이저 및 미용 기기 실무', '필 링 및 화학박피', '코스메슈티컬 및 메디컬 스킨케어 약물의 종류', '스 켈프 케어', '비만관리', '메디컬 스킨케어 시술', '위생관리'로, 각각의 책무는 2-5개의 작업(task)으로 구성하였으며, 구체적인 직무기술 을 작성하였다. 메디컬 스킨케어 종사자의 책무와 작업은 Table 3 과 같다.

\section{3. 메디컬 스킨케어 종사자의 직무 중요도, 난이도 및 활용 빈도 DACUM 결과}

DACUM 위원회 워크솝을 통해 추출된 9 개의 책무와 18 개의 수행 작업을 워크숍에 참여한 전문가를 대상으로 중요도와 난이도 및 활 용 빈도를 Likert 5 점 척도를 사용해 측정을 실시하였으며 그 결과는 $\mathrm{A}$ (높다)는 4-5점, B (보통)은 3점, C (낮다)는 1-2점으로 구분해 표시했다. 그 결과 메디컬 스킨케어 종사자 직무 중 '병원 실무 알기' 와 '인체 해부 생리 지식 이해하기', '기기 실무 이해하기'에서 수행 작 업의 중요도, 난이도, 활용 빈도에서 모두 높게 나타났다. 반면 '모발 생리학 이해하기'와 '비만관리 이해하기', '보톡스-필러·지방이식· 실리

Table 3. Job description of a medical skincare worker

\begin{tabular}{|c|c|c|}
\hline Form & Task & Elements of the task \\
\hline \multirow{2}{*}{$\begin{array}{l}\text { A. Medical skincare hospital } \\
\text { reception practice }\end{array}$} & A1. Medical skincare job definition & \multirow{2}{*}{$\begin{array}{l}\text { Medical skincare and worker job definition and purpose, } \\
\text { Customer response and consultation }\end{array}$} \\
\hline & A2. Hospital reception practice & \\
\hline B. Problem in skin analysis & $\begin{array}{l}\text { B1. Understanding physiological knowledge of human } \\
\text { anatomy }\end{array}$ & $\begin{array}{l}\text { Physiological function of the skin, Problem in skin types } \\
\text { (sensitive, atopic, acne, pigmented, aging skin) features } \\
\text { classification, Ability to identify problem in skin }\end{array}$ \\
\hline \multirow{2}{*}{$\begin{array}{l}\text { C. Laser and cometic device } \\
\text { practice }\end{array}$} & C1. Laser understanding & \multirow{2}{*}{$\begin{array}{l}\text { Classification of application according to cosmetic laser } \\
\text { characteristics, Regeneration management after laser, } \\
\text { Beauty device management method and effect }\end{array}$} \\
\hline & C2. Understanding of beauty device practice & \\
\hline \multirow{2}{*}{$\begin{array}{l}\text { D. Peeling and chemical } \\
\text { peeling }\end{array}$} & D1. Understanding peeling & \multirow{2}{*}{$\begin{array}{l}\text { Peeling definition and types and effects, Regeneration } \\
\text { management after chemical peeling }\end{array}$} \\
\hline & D2. Understanding chemical peeling & \\
\hline \multirow{2}{*}{$\begin{array}{l}\text { E. Cosmeceutical types of } \\
\text { medical skincare drugs }\end{array}$} & E1. Understanding cosmeceuticals & \multirow{2}{*}{$\begin{array}{l}\text { Cosmeceutical concept and ingredient classification, } \\
\text { Medical skincare drug classification }\end{array}$} \\
\hline & E2. Medical skincare drug classification & \\
\hline \multirow{2}{*}{ F. Scalp care } & F1. Understanding the physiology of hair & \multirow{2}{*}{$\begin{array}{l}\text { Hair physiology, Factors and classification of hair loss, } \\
\text { Treatment method, Mesotherapy, TA (Triamcinolone) } \\
\text { injection therapy }\end{array}$} \\
\hline & F2. Classification of hair loss types & \\
\hline G. Obesity management & G1. Understanding obesity management & $\begin{array}{l}\text { Obesity, Cellulite management, Mesotherapy and } \\
\text { carboxytherapy principles, Obesity device }\end{array}$ \\
\hline \multirow{5}{*}{$\begin{array}{l}\text { H. Medical skincare beauty } \\
\text { treatment }\end{array}$} & H1. Preparing for botox injection & \multirow{5}{*}{$\begin{array}{l}\text { Botox and filler features and treatment site, precautions, } \\
\text { Self-fat transfer transplantation effect and cautions, PRP } \\
\text { features and treatment effects, Thread lift procedure } \\
\text { method and precautions }\end{array}$} \\
\hline & H2. Preparing for filler injection & \\
\hline & H3. Understanding fat transplantation & \\
\hline & H4. Understanding (PRP) autologous skin regeneration & \\
\hline & H5. Understanding thread lift & \\
\hline I. Hygiene management & $\begin{array}{l}\text { I1. Understanding the types and methods of } \\
\text { disinfection }\end{array}$ & $\begin{array}{l}\text { Definition and classification of disinfection method, } \\
\text { Preparation of disinfection set, Dressing preparation }\end{array}$ \\
\hline
\end{tabular}

PRP, platelet rich plasma. 
프팅 시술 이해하기'에서 수행작업의 중요도 및 난이도, 활용 빈도에 서 모두 낮게 나타났다. '레이저 알기', '필링의 정의와 종류 알기', '화 학박피 이해하기', '메디컬 스킨케어 약물 분류하기', 'PRP 이해하기', '소독의 종류 및 방법 이해하기'의 중요도와 활용 빈도가 높게 나타났 다. 메디컬 스킨케어 종사자의 직무 중요도, 난이도, 및 활용 빈도 데 이컴 결과는 Table 4 와 같다.

\section{Discussion}

본 연구는 의료 뷰티 시장의 확대로 전문적인 메디컬 스킨케어 종 사자의 필요성이 증가함에 따라 그 직무분석을 목적으로 진행한 서 술적 조사연구로서 다음과 같이 논의하고자 한다.

첫째, Ahn \& Kim (2010)의 연구에서 메디컬 스킨케어는 피부과 전문의의 정확한 피부진단 후 의학적 치료와 피부관리를 함께 병행 하는 것으로 피부를 빠르게 정상화시켜 주는 것이라 정의하였다. 본 연구에서도 메디컬 스킨케어 종사자의 직무를 피부과 전문의를 통해 피부의 문제에 관해 전문적인 진단을 받은 고객을 미용의료 프로그 램을 적용한 의료기기 사용과 코스메슈티컬 화장품을 이용한 관리를 수행하는 직무로 정의하였다. 이것으로 메디컬 스킨케어 종사자의 직무를 정의하여, 피부관리실 이용 고객과 메디컬 스킨케어를 이용 하는 고객의 방문 목적의 차이를 구분하여 직무를 수행할 수 있을 것
으로 사료된다.

둘째, DACUM 결과, 메디컬 스킨케어 종사자의 직무를 도출하였 다. Lee \& Choi (2018)의 연구에서 메디컬 스킨케어 직무 모형을 개 발하고자 하였으나, NCS에서 보건 분야 중 '병원 안내(병원코디네 이터)'와 이·미용에서 '피부미용' 능력 단위를 발췌한 것으로 실질적 인 메디컬 스킨케어 현장에서의 직무를 기술하기에는 부족하였다. 이에 본 연구에서 현재 메디컬 현장에서 실제적으로 진행되는 직무 를 기술한 결과 피부미용사의 경우 병원 취업 후 피부관리 업무보다 진료보조의 역할 비중이 높은 것으로 보였다. 실제로 병원에서 근무 하는 피부관리사가 간호조무사 자격증을 취득하는 경우가 증가하고 있다. Jung \& Park (2015)의 연구에 의하면 메디컬 스킨케어에 종 사하는 피부관리사는 피부미용 업무에 대한 만족도는 높으나, 간호 업무와 피부미용 업무를 병행하기를 희망한다고 하였다. 연구 결과 에 의하면 간호조무사 자격증 취득자와 미취득자 간에 간호보조 업 무 중 외래 보조업무만 유의성 있는 결과를 보였고 고객 관리, 수술 보조, 시술 보조, 기기관리, 화장품 판매 등과 같은 병원 내 모든 관 련 실무에서 유의성이 없는 것으로 나타났다. 또한 간호조무사 자격 취득 후 봉급이나 승진 등의 처우개선에 크게 차이가 없었다. 이것은 간호조무사 자격증 미취득자이던 취득자이던 메디컬 스킨케어 업무 와 간호보조 업무가 분리되지 않음을 시사하는 것으로 보유 자격증 에 따라 업무를 분리하여 담당하도록 개선해야 할 것을 제언하고자 한다. Ahn \& Kim (2010)도 메디컬 스킨케어 현장은 의료인의 진료

Table 4. Job importance, difficulty, and frequency of use of medical skincare workers

\begin{tabular}{|c|c|c|c|c|}
\hline Duty & Task & Importance & Difficulty & Usage frequency \\
\hline \multirow{2}{*}{$\begin{array}{l}\text { A. Medical skincare hospital } \\
\text { reception practice }\end{array}$} & A1. Medical skincare definition & $\mathrm{B}$ & $\mathrm{C}$ & $\mathrm{C}$ \\
\hline & A2. Hospital reception practice & A & $A$ & A \\
\hline B. Problem in skin analysis & $\begin{array}{l}\text { B1. Understanding physiological knowledge of } \\
\text { human anatomy }\end{array}$ & A & A & A \\
\hline \multirow{2}{*}{$\begin{array}{l}\text { C. Laser and cometic device } \\
\text { practice }\end{array}$} & C1. Laser understanding & A & $\mathrm{B}$ & A \\
\hline & C2. Understanding of beauty device practice & A & $A$ & A \\
\hline \multirow{2}{*}{$\begin{array}{l}\text { D. Peeling and chemical } \\
\text { peeling }\end{array}$} & D1. Understanding peeling & A & $\mathrm{C}$ & A \\
\hline & D2. Understanding chemical peeling & A & $\mathrm{B}$ & A \\
\hline \multirow{2}{*}{$\begin{array}{l}\text { E. Cosmeceutical types of } \\
\text { medical skincare drugs }\end{array}$} & E1. Understanding cosmeceutical & $\mathrm{B}$ & $\mathrm{C}$ & $\mathrm{B}$ \\
\hline & E2. Medical skincare drug classification & A & $\mathrm{B}$ & A \\
\hline \multirow{2}{*}{ F. Scalp care } & F1. Understanding the physiology of hair & $\mathrm{C}$ & $\mathrm{C}$ & $\mathrm{C}$ \\
\hline & F2. Classification of hair loss types & B & $\mathrm{C}$ & $\mathrm{C}$ \\
\hline G. Obesity management & G1. Understanding obesity management & C & $\mathrm{C}$ & $\mathrm{C}$ \\
\hline \multirow{5}{*}{$\begin{array}{l}\text { H. Medical skincare beauty } \\
\text { treatment }\end{array}$} & H1. Preparing for botox injection & $\mathrm{C}$ & $\mathrm{C}$ & $\mathrm{C}$ \\
\hline & H2. Preparing for filler injection & C & $\mathrm{C}$ & $\mathrm{C}$ \\
\hline & H3. Understanding fat transplantation & $\mathrm{C}$ & C & $\mathrm{C}$ \\
\hline & $\begin{array}{l}\text { H4. Understanding (PRP) autologous skin } \\
\text { regeneration }\end{array}$ & A & $\mathrm{C}$ & A \\
\hline & H5. Understanding thread lift & $\mathrm{C}$ & $\mathrm{C}$ & $\mathrm{C}$ \\
\hline I. Hygiene management & $\begin{array}{l}\text { I1. Understanding the types and methods of } \\
\text { disinfection }\end{array}$ & A & $\mathrm{B}$ & A \\
\hline
\end{tabular}

A, high score (4-5); B, middle score (3); C, low score (1-2). 
보조와 피부관리의 고유 업무를 동시에 수행해야 하므로 이론, 테크 닉, 시술, 고객관리 등 업무 구분을 명확히 하여야 한다고 강조하였 다. 이러한 메디컬 스킨케어 종사자의 직무 분석을 통해 피부관리사 와 간호조무사의 업무의 분리가 필요하다.

셋째, DACUM 결과 메디컬 스킨케어 직무에서 '병원 리셉션 실무 알기', '인체 해부 생리지식 이해하기', '미용기기 실무 이해하기'가 중 요도, 난이도, 활용 빈도에서 높게 나타나 피부미용 전공 교과목과 부합하는 것으로 볼 수 있다. 직무의 수행도는 실제로 많이 하는 직 무를 나타내며, 난이도는 일을 수행하는데 어려운 정도를 의미하는 것으로(Mo \& Oh, 2019), 직무에 대한 중요도와 활용 빈도는 밀접한 연관성이 있을 것으로 보였다. 본 연구에서 병원 리셉션 실무, 문제 성 피부분석, 레이저 및 미용 기기 실무, 필링 및 화학박피, 코스메슈 티컬 및 메디컬 스킨케어 약물의 종류, 스켈프 케어 중 모발의 생리 이해, 비만관리, 메디컬 스킨케어 시술, 위생관리에서 모두 중요도 와 활용 빈도 수준이 동일하게 나타나 직무의 중요도와 활용 빈도의 연관성을 보여주었다. Lee \& Lim (2016)에 의하면 전공내용이 직무 에 필요한 지식과 능력에 일치함으로써 직무 수행에 도움이 되는 정 도를 직무에 대한 전공 활용도의 개념으로 보았다. 본 연구에서 인체 해부지식과 미용기기 실무에서 직무의 중요도, 난이도, 활용 빈도에 서 높게 나타난 것은 메디컬 스킨케어 직무에서 전공 활용도가 높은 것으로 볼 수 있다.

넷째, DACUM 결과 코스메슈티컬 이해의 중요도는 낮게 나타난 반면, 메디컬 약물 분류의 중요도와 활용 빈도는 높게 나타났다. 코 스메슈티컬이란 cosmetic (화장품)과 pharmaceutical (의약품)의 합 성어로 피부과 전문의들이 연구개발과 임상에 주도적으로 참여하 여 생산해내는 '기능성 화장품'을 말한다. 최근 코스메슈티컬 화장품 은 피부과 전문의가 직접 기획하거나 개발 과정에 관여하여 병원을 브랜드화한 화장품과 화장품 기업에서 전문 의사들과의 제휴 등을 통해서 공동으로 개발된 제품으로 나누어지고 있다(Park \& Kwon, 2017). Kim \& $\operatorname{Han}$ (2018)의 메디컬 화장품 선호도 조사결과에 의 하면 피부과를 브랜드화한 메디컬 화장품은 구매하겠다고 하였으나. 일반 화장품 회사의 메디컬 화장품은 잘 모르겠다는 응답이 많았다. Park \& Kwon (2017)의 연구에서도 실제 소비자들은 코스메슈티컬 화장품의 실제효능에 대해 일반 화장품과 차별성을 인지하지 못하는 것으로 나타났다. 본 연구에서도 코스메슈티컬 이해보다 메디컬 스 킨케어에서 사용하는 약물 분류에서 직무의 중요도 및 활용 빈도가 높게 나타나 이러한 내용을 뒷받침하는 것으로 보였다. 최근 미세먼 지와 같은 환경오염과 고령화로 인한 피부 면역력 저하 등으로 피부 에 안전한 화장품을 찾게 되었을 뿐 아니라(Kang, 2017), 성형과 미 용시술의 증가로 시술 이후 관리에 대한 수요가 증가하고 있어 코스 메슈티컬 제품이 부상하고 있다. Hong \& Kim (2020)의 연구에 의 하면 개인의 특성에 맞는 화장품 조제 과정에 피부미용사들의 임상 경험이나 기술적 역량이 더 해진다면 큰 효과를 발휘할 것이라고 하
였다. 이에 메디컬 스킨케어 종사자들은 코스메슈티컬 성분에 대한 관심의 증가와 함께 맞춤형 화장품 조제시대를 맞이하여 메디컬에서 코스메슈티컬 화장품 조제 상담가로서 충분히 직무역량을 발휘할 수 있을 것으로 사료된다.

다섯째, DACUM 결과 메디컬 스킨케어 시술에서 보톡스, 필러, 지방이식, 실리프팅 등 준비하기에 대해 중요도와 난이도, 활용 빈도 가 낮게 나타난 반면, 중요도와 활용 빈도에서 'PRP 이해하기'가 높 게 나타났다. 메디컬 스킨케어 시술 전 준비는 의료보조의 역할로 피 부미용사로서의 전문적인 직무가 필요치 않아서 결과가 낮게 나타난 것으로 보였다. $\mathrm{PRP}$ 란 platelet rich plasma의 약자로 혈소판이 풍 부한 혈장으로 본인의 혈소판을 분리하여 주입하는 시술로 자가혈 피부재생술이라 불린다. 최근 칼을 대지 않고 빠른 시간 내에 효과를 얻을 수 있는 비수술적 성형술로 경쟁력 있는 동안 얼굴을 위한 쁘 띠 성형의 한 방법으로 최근 주목받고 있으며, 보톡스와 필러가 대표 적이다. 국내 필러 시장은 2009년 189억 원에서 2014년 1,000억 원 으로 연평균 약 $40 \%$ 성장하여 지속적인 성장세를 보이고 있다 $(\mathrm{Kim}$, 2019b). 이와 같이 쁘띠 성형이 최근 피부과와 성형외과에서 많은 인기를 얻고 있어 자가혈을 이용해 부작용을 최소화한 PRP자가혈 피부재생술에 대한 관심의 증가로 중요도와 활용 빈도에서 높은 결 과를 보인 것으로 사료된다. Oh \& Mo (2019)의 연구에서 보강해야 할 직무영역에 관한 연구에서 새로운 시술요법에 대한 보강이 필요 하다는 연구결과가 있어 메디컬 스킨케어 종사자들의 피부과학적 지 식을 바탕으로 지속적으로 새로운 시술요법에 적응해야 하는 것으로 보였다. 이에 본 연구에서 DACUM 위원들이 최신 기술인 PRP자가 혈 피부 재생술에 대한 적응이 직무에 있어 중요하게 나타난 것으로 보였다.

여섯째, DACUM 결과 메디컬 위생관리의 중요도와 활용 빈도가 높게 나타났다. Oh \& Mo (2018)의 메디컬 피부관리사의 직무 역할 에 관한 연구에서도 소독 위생부분에서 소모품 관련 소독 유지 및 관 리를 강화해야 한다는 결과가 있어 본 연구에서 위생관리에 대한 결 과와 일치하였다. 이것은 메디컬 스킨케어가 일반 피부관리실과 달 리 의료적 환경의 영역에 속하여 소독에 대한 개념과 업무의 중요성 을 보여주는 것이다. 최근 코로나 19 로 청결과 개인위생에 대한 관심 이 증가하면서 무엇보다도 메디컬 스킨케어 현장에서 우리는 소독 위생에 대한 중요성을 인지하고 강화해야 할 것이다.

\section{Conclusion}

이와 같이 본 연구에서는 메디컬 스킨케어 종사자의 직무기술을 토대로 전문성을 강화하고 이를 업무에 적용할 수 있는 표준화된 메 디컬 스킨케어 종사자의 교육과정이 개발되어야 할 것이다. DACUM 기법을 이용하여 메디컬 스킨케어 종사자의 책무와 작업을 구분하여 
직무의 중요도와 난이도, 활용 빈도를 도출하였다. 데이컴 결과 메디 컬 스킨케어 직무 중에서 '병원 리셉션 실무 알기', '인체 해부 생리지 식 이해하기', '미용기기 실무 이해하기' 중요도, 난이도, 활용빈도가 높게 나타났으며, 메디컬 위생관리의 중요도와 활용빈도가 높게 나 타났다.

이러한 데이컴 결과를 메디컬 스킨케어 종사자의 교육에 반영하 고, 추후 연구에서 메디컬 스킨케어 종사자의 직무 내용을 현장 종사 자들에게 검증하고 내용을 분석하는 후속 연구가 필요하다. 또 메디 컬 스킨케어에서 피부관리사의 현행 업무를 분석하고 단계별 업무의 범위를 체계화하여 메디컬 스킨케어 산업 및 교육현장에서 기초 자 료로 제공하고자 한다.

This work is part of the Sumin Lee's M.S. thesis at the University of Sungkyul, Anyang-si, Gyeonggi-do, Korea.

\section{Author's contribution}

The introduction, research methods, analysis of results, and references were drafted by SL. HC and JL reinterpreted this, comparatively analyzed the results, and added references.

\section{Author details}

Sumin Lee (Teacher), Department of International Beauty Arts, Seoul Life Science High School, 1355-10, Oriro, Guro-gu, Seoul 08248, Korea; Jaeeun Lee (Visiting professor), Department of Beauty Design, Sungkyul University, 53, Seonggyeoldaehak-ro, Manan-gu, Anyangsi, Gyeonggi-do 14097, Korea; Haejung Chon (Professor), Department of Beauty Design, Sungkyul University, 53, Seonggyeoldaehak-ro, Manan-gu, Anyang-si, Gyeonggido 14097, Korea.

\section{References}

Ahn MR, Kim YS. A study on critical factors affecting the sanitary behavior of medical esthetician. Asian Journal of Beauty and Cosmetology, 8: 237-247, 2010.

Hong JY, Kim YS. Improving the system of the national qualification test for customized cosmetic preparation managers. Asian Journal of Beauty and Cosmetology, 18: 341-354, 2020.

Jang HJ. A study of current use and interest in medical skin care among $20^{\prime}$ women student on college. Asian Journal of Beauty and Cosmetology, 23: 883-893, 2017.

Jung EY, Park MY. Work patterns and job conditions of estheticians and nursing assistants working at the medical skincare area. Asian Journal of Beauty and Cosmetology, 13: 865-872, 2015.

Kang SH, Lee MO. The effect of hospital coordinator role reaches to the customer satisfaction and performance of organization. Korean Journal of Local Government \& Administration Studies, 26: 215-229, 2012.

Kang YN. The effects of cosmeceutical product choice by hospital workers on their consumption values. Journal of Beauty Art Management, 11: 1-20, 2017.

Kim KJ, Han HS. Marketing strategies and consumer recognition of medical cosmetics. Asian Journal of Beauty and Cosmetology, 16: 569-578, 2018.

Kim ND, Jeon MY, Choi JH, Lee HE, Lee JY, Lee SJ, Seo YH, Kwon JY, Han DH. Trend Korea 2021. Window of the future, Seoul, pp252-270, 2020.

Kim KY. A study on the way that can have the beauty industry's competitiveness through the Korean wave. The Treatise on The Plastic Media, 18: 11-28, 2015.

Kim D. A study on analysis of visual elements of brand package design in dermal filler. Journal of Cultural Product \& Design, 56: 227-237, 2019b.

Kim MJ. Affecting factors for job stress and client service of estheticians in the medical beauty industry. Asian Journal of Beauty and Cosmetology, 17: 157-168, 2019a.

Kim JW, Kim JS. DACUM job analysis of management teacher of industry-academy cooperation of specialized high school. Journal of the Korean Institute of Industrial Educators, 43: 76-93, 2018.

Kim YJ, Park GS, Park JY, Lee EW, Lee JE, Jeong SH, Cho SY, Choi SI, Choi YJ, Hong JK. Hospital coordinator for hairdressers. Medician, Seoul, pp106-111, 2020.

Kwon YM, Cho KM, Joo HJ, Kim SJ, June KJ, Park EH. Development of job description of HIV/AIDS counselling nurse in Korea. Journal of Korean Academy of Nursing Administration, 15: 91-105, 2009.

Kim YJ, Kim NY, Choi EY. Medical skin care. Guminsa, Seoul, pp13-184, 2017.

Kim HJ, Lim JS, Choi SM, Park SH, Park SH ,An SE, Kim HJ, Kim ES, Jung IA, Kim S. Analysis of activities and services of delivery room nurses based on DACUM technique. Journal of Korean Clinical Nursing Research, 21: 319-334, 2015. 
Lee JE, Choi EY. A study on the state of medical skincare and satisfaction level. Journal of Korean Society of Cosmetics and Cosmetology, 5: 73-87, 2015.

Lee SY, Lim K. Analyses on the differences in major-job related variables between traditional and national competency standards recruitment systems: focused on science and engineering fields employees. Journal of Knowledge Information Technology and Systems, 11: 583-596, 2016.

Lee SH, Choi EY. A study on the curriculum for national competency standard (NCS) on competency unit element of medical skin care. Asia-pacific Journal of Multimedia Services Convergent with Art, Humanities, and Sociology, 8: 491-500, 2018.

Lee SM, Kim YH, Shim YM, Choi JS, Yu M. Development of hospital nurses job description based on DACUM method: focusing on general ward and intensive care unit. Journal of Korean Academy of Nursing Administration, 23: 535547, 2017.

Lee SY, Lim K. Analyses on the differences in major-job related variables between traditional and national competency standards recruitment systems: focused on science and engineering fields employees. Journal of Knowledge Information Technology and Systems, 11: 583-596, 2016.

Lee HY, Lee KA. The occupational conditions of medical skincare estheticians working in the dermatology clinics. Asian Journal of Beauty and Cosmetology, 10: 69-78, 2012.

Lee SN, Kang SO, Hong YH. Medical skin care. Hunminsa, Seoul, pp13-184, 2013.
Mo JH, Oh SJ. Analysis of job performance and difficulty for medical skin care employees. Journal of the Korean Society of Beauty and Art, 21: 37-50, 2019.

Min JH, Kim J. A study on the healing tourism coordinator's job using DACUM. The Journal of Humanities and Social Science, 10: 153-165, 2019.

Oh SJ, Mo JH. A job analysis of medical estheticians using IPA. Journal of the Korean Society of Design Culture, 24: 391400, 2018.

Park SH, Kwon HJ. Customers' convergent recognition and satisfaction about cosmeceuticals. Journal of Digital Convergence, 15: 459-464, 2017.

Pyo YH, Park EK, Lee HY, Lee EJ. Medical skin care. Powerbook, Seoul, pp13-193, 2018.

Shin JY, Kim JD. A study on awareness of medical skincare and satisfaction. Journal of the Korean Society of Cosmetology, 15: 786-802, 2009.

Sim EK. The correlation between job stress and service quality of employees in the medical beauty service industry. Journal of the Korean Society of Cosmetology, 21: 12-20, 2015.

Yoo HS, Shim SY, Kim MS. The job analysis of head hospital coordinators based on the DACUM method. Korean Journal of Hospital Management, 21: 37-52, 2016.

Yun HJ, Jung EH, Jung WS, Lee SR, Kwon YO. Nurses' job analysis in a regional emergency center using the DACUM. Journal of Korean Clinical Nursing Research, 26: 21-26, 2020. 


\section{국문초록}

\section{데이컴 기법을 이용한 메디컬 스킨케어 직무 연구}

이수민 ${ }^{1}$, 이재은 ${ }^{2}$, 전해정 ${ }^{1 *}$

${ }^{1}$ 서울생활과학고등학교 국제뷰티아트과, 서울, 한국

${ }^{2}$ 성결대학교 뷰티디자인학과, 경기도 안양시, 한국

목적: 본 연구의 목적은 DACUM 기법을 적용해 메디컬 스킨케어에서 피부관리사의 직무를 정의하고 기술하여 단계별 업무의 범위 를 체계화하고자 한다. 또한 직무의 중요도, 난이도, 활용 빈도를 확인하여 메디컬 스킨케어 산업 및 교육현장에서 활용할 수 있는 기초 자료로 제공하고자 한다. 방법: 메디컬 스킨케어 종사자의 직무 연구를 위하여 현장 실무 경험이 많은 전문가 5 명을 DACUM 위원으로 선정하였다. DACUM 분석 결과 메디컬 스킨케어 종사자의 직무를 9 개의 책무와 18 개의 작업으로 도출되었다. 결과: 본 연구에서 메디컬 스킨케어 종사자의 직무를 피부과 전문의를 통해 피부의 문제에 관해 전문적인 진단을 받은 고객에게 미용의료 프 로그램을 적용한 의료기기 사용과 코스메슈티컬 화장품을 이용한 관리를 수행하는 것으로 정의하였다. 데이컴 결과 메디컬 스킨케 어 직무 중에서 '병원 리셉션 실무 알기', '인체 해부 생리지식 이해하기', '미용기기 실무 이해하기' 중요도, 난이도, 활용빈도가 높게 나타났으며, 메디컬 위생관리의 중요도와 활용빈도가 높게 나타났다. 결론: 본 연구를 통해 메디컬 스킨케어 종사자 직무의 표준화 를 제시하고 교육과정 개발에 자료로 활용되기를 바란다.

핵심어: DACUM 기법, 메디컬 스킨케어 종사자, 메디컬 스킨케어, 책무, 작업

\section{참고문헌}

김경진, 한효선. 메디컬 화장품의 마케팅 전략과 소비자 인식도. 아시안뷰티화장품학술지, 16: 569-578, 2018.

김기영. 한류를 통한 뷰티 산업의 경쟁력 강화 방안 연구. 한국일러스트학회지, 18:11-28, 2015.

김난도, 전미영, 최지혜, 이향은, 이준영, 이수진, 서유현, 권정윤, 한다혜. 트렌드 코리아 2021. 미래의창, 서울, pp252270, 2020.

김두한. 더말 필러(Dermal Filler) 브랜드 패키지디자인의 시각적 요소에 관한 연구. 한국상품문화디자인학회지, 56 : 227-237, 2019b.

김문주. 병원 내 피부미용사의 직무 스트레스와 대 고객 서비스 관련 요인. 아시안뷰티화장품학술지, 17:157-168, 2019a.

강순화, 이미옥. 병원코디네이터 직무역할이 고객만족 및 조직성과에 미치는 영향. 한국자치행정학회지, $26: 215-229$, 2012.

강유나. 병원종사자의 코스메슈티컬에 대한 제품선택이 소비가치에 미치는 영향. 미용예술경영연구, 11: 1-20, 2017.

김영주, 박경선, 박정연, 이은우, 이재은, 정선희, 조선영, 최성임, 최윤정, 홍재기. 미용인을 위한 병원코디네이터. 메디시 언, 서울, pp106-111, 2020.

김유정, 김나영, 최은영. 메디컬 스킨케어. 구민사, 서울, $\mathrm{pp} 13-184,2017$.

김종욱, 김진수. 데이컴(DACUM) 기법을 활용한 특성화고 산학협력부장 교사의 직무 분석. 대한공업교육학회지, $43: 76-$ 93, 2018.

김현주, 임종순, 최선미, 박소희, 박수혜, 안성은, 김희정, 김은실, 정인아, 김수. 데이컴기법을 활용한 분만실 간호사의 업 무활동 분석. 임상간호연구, 21: 319-334, 2015.

권영미, 조경미, 주혜주, 김성재, 전경자, 박은희. 에이즈 상담간호사 자격제도 개발을 위한 직무 분석: 포커스 그룹 연구 방법과 데이컴 기법을 중심으로. 간호행정학회지, 15: 91-105, 2009. 
모정희, 오수정. 메디컬 스킨케어 종사자의 직무 수행도와 난이도 분석. 한국인체예술학회지, 21: 37-50, 2019. 민제호, 김지인. 데이컴기법을 활용한 치유관광코디네이터 직무연구. 인문사회 21, 10: $153-165,2019$. 박수하, 권혜진. 코스메슈티컬 화장품에 대한 소비자들의 복합적 인식 및 만족도. 디지털융복합연구, 15: 459-464, 2017. 신진영, 김주덕. 메디컬 스킨케어의 인식 및 만족도에 관한 연구. 한국미용학회지, 15: 786-802, 2009. 심은경. 의료미용서비스산업 종사자의 직무스트레스와 서비스 품질과의 관련성. 한국미용학회지, 21: $12-20,2015$. 안미령, 김윤신. 메디컬 스킨케어 관리사의 보건행위 실천에 미치는 주요 요인에 관한 연구. 아시안뷰티화장품학술지, 8: 237-247, 2010.

오수정, 모정희. IPA를 활용한 메디컬 에스테티션의 직무 분석. 한국디자인문화학회지, 24: 391-400, 2018.

유형식, 심소영, 김미숙. DACUM 기법에 의한 병원코디네이터실장의 직무분석 연구. 한국병원경영학회지, $21: 37-52$, 2016.

윤희제, 정은희, 정운선, 이상림, 권영옥. 데이컴 기법을 이용한 일개 권역응급의료센터 간호사의 직무 분석. 임상간호연 구, 26: 21-26, 2020.

이선미, 김연희, 심유미, 최진선, 유미. DACUM 기법을 활용한 상급종합병원 간호사의 직무기술서 개발: 일반병동과 중환 자실을 중심으로. 간호행정학회지, 23: 535-547, 2017. 이성내, 강신옥, 홍양희. 메디컬 스킨케어. 훈민사, 서울, $\mathrm{pp} 13-184,2013$.

이세희, 최은영. 메디컬스킨케어 능력단위 개발을 위한 국가직무능력표준 (NCS) 을 위한 교육과정 연구. 예술인문사회융 합멀티미디어논문지, 8: 491-500, 2018.

이소예, 임걸. 기존 및 NCS채용제도의 전공-직무연계 관련 변인 차이분석: 이공계 직장인을 중심으로. 한국지식정보기술 학회 논문지, 11: 583-596, 2016.

이정은, 최은영. 메디컬 스킨케어의 실태 및 만족도에 관한 연구. 한국화장품미용학회지, 5: 73-87, 2015.

이혜영, 이경애. 피부과에 근무하는 메디컬스킨케어 에스테티션의 근무현황. 대한피부미용학회지, 10: 69-78, 2012. 장혜진. 20대 여대생의 메디컬 스킨케어의 이용 실태와 관심도에 관한 연구. 한국미용학회지, 23: 883-893, 2017.

정은영, 박미영. 피부미용사의 간호조무사 자격 취득에 따른 업무실태 조사. 아시안뷰티화장품학술지, 13: 865-872, 2015.

표영희, 박은경, 이혜영, 이은주. 메디컬 스킨케어. 파워북, 서울, pp13-193, 2018.

홍지유, 김영삼. 맞춤형화장품조제관리사 국가자격시험제도 개선방향성에 대한 연구. 아시안뷰티화장품학술지, 18: $341-$ 354, 2020. 


\section{中文摘要}

\section{利用DACUM法研究医疗护肤工作}

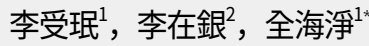

1首尔生活可续高等学校国际美容艺术学科，首尔，韩国

圣洁大学美容设计学科, 京畿道安养市, 韩国

目的: 本研究旨在通过应用开发课程（DACUM）技术逐步定义和描述医学护肤美容师的工作，使工作范围系 统化。此外，检查并提供了该工作的重要性、难度和使用频率，作为可用于医疗护肤行业和教育网站的基础 数据。方法: 针对医学护肤工作者的工作调研, 共选择5名具有丰富现场经验的专家作为DACUM成员。作为 DACUM 分析的结果, 医疗护肤工作者的工作来自 9 个职责和 18 个任务。结果: 在本研究中, 医学护肤工作者 的工作被定义为使用具有美容医疗计划的医疗器械和药妆产品管理, 这些产品适用于由皮肤科医生专业诊断出 皮肤问题的客户。因达康, 在医疗护肤岗位中, “了解医院接待实践”、“了解人体解剖生理知识”、“了解美容设 备实践”的重要性、难度和使用频率均较高。“医疗卫生管理”的重要性和使用频率也很高。结论: 本研究的结果 提出了医学护肤工作者工作的标准化，并为课程开发提供了数据。

关键词: 开发课程, 医疗护肤工作者, 医疗护肤, 职责, 任务 
